\title{
MONETARY CIRCULATION AND BANKS IN THE INTERPRETATION OF THE MAIN ECONOMIC SCHOOLS
}

\author{
Maryna Korol ${ }^{1}$, Ihor Korol ${ }^{2}$, Olena Zayats ${ }^{3}$
}

\begin{abstract}
The topicality of the research lies in the fact that the long-term evolution of financial markets, reinforced by global transformations, has led to the development of convergent processes in banking activities in the presence of significant paradigmatic differences between the major banking systems of the world. The existing peculiarities in the mechanisms and methods of regulation of the banking sector within individual countries have caused drastic changes in views on the nature of the bank and its activities. The traditional view of banks as institutions of financial intermediation, providing the exchange of monetary assets between the owners of savings and borrowers, does not provide for the creation of new money. Instead, proponents of the alternative viewpoint emphasize that in today's world banks finance borrowers mainly through the mechanism of money emission. Both points of view are present to varying degrees in various theoretical and conceptual approaches to understanding the essence of the bank as an institution of financial intermediation. The current economic realities require a detailed study of national banking systems, which largely developed historically, and methodological aspects of their evolution in the context of global transformations. The research subject. In the process of evolution of theoretical and conceptual approaches to the definition of the essence of money, banks, the banking system, the prevailing point of view on this issue has not yet taken a definite form. Nevertheless, the recognition of the effectiveness of banks as a factor of economic growth brings together the positions of competing schools of economic theory. Banks become a factor in the investment process even in the theoretical models of the neoclassical school, which traditionally denies the dependence of economic growth on the money supply. Endogenous growth models recognize the role of banks primarily as a factor in accumulating capital and increasing savings, as well as a mediator between owners of savings and borrowers. Although the Keynesian school of thought initially gave little weight to the functioning of the banking system, neo-Keynesian models have attempted to explain the importance of confidence in the banking system and the need for sound regulatory constraints. The above-mentioned has urged us to carry out this research. The methodological framework of the research is based on an analysis of research on the global debate about the nature of banks in the economy and the architecture of monetary policy. A wide range of theoretical and empirical research methods were used: systematic analysis, synthesis and generalization to formulate conclusions. The aim of the research is to generalize and systematize the evolution of perspectives on money in the interpretations of today's main economic schools. Conclusion. The findings consist of a conceptualization views' evolution on money, the banking sector in a more open economy to capital flows, and our firm belief that the banking system and the related process of money issuance affect income levels cyclically and over the long term.
\end{abstract}

Key words: money, banks, banking system, economic schools, globalization.

JEL Classification: E51, E59, G21, G34

\footnotetext{
Corresponding author:

${ }^{1}$ Uzhhorod National University, Ukraine.

E-mail: maryna.korol@uzhnu.edu.ua

ORCID: https://orcid.org/0000-0003-4031-0858

${ }^{2}$ John Paul II Catholic University of Lublin, Poland.

E-mail: ihorkorol@kul.lublin.pl

ORCID: https://orcid.org/0000-0001-7826-0249

${ }^{3}$ Uzhhorod National University, Ukraine.

E-mail: olena.zayats@uzhnu.edu.ua

ORCID: https://orcid.org/0000-0001-9904-8706
} 


\section{Introduction}

In the fundamental works of foreign and domestic scientists presented the theoretical and methodological basis for the interpretation of the essence of money, banking and functioning of banking systems. Nevertheless, theoretical approaches to the positioning of money and the banking system in contemporary models of monetary policy, which differ in terms of competing schools of economic theory, need to be improved. Today there is no dominant viewpoint on either of these two issues. The paradigm of monetary policy is determined by the traditional assumption about money neutrality in relation to income and relatively new elements regarding the endogeneity of the money supply and the institutional role of the banking system in the process of crediting the economy.

In the context of different theoretical approaches to the evolution of the interpretation bank's essence and the banking system, we proposed an improved definition: the Bank - a financial institution endowed with economic and legal independence, carrying out banking operations in the field of monetary policy and money circulation, the ultimate goal of which is to make a profit and/or to meet customer needs. Even if there is no profit goal, then it is customer satisfaction that remains the goal of the bank, as in Islamic banks.

The various issues of the functioning of the banking system can hardly be separated from the existing monetary regime or, in a broader sense, from the conceptual views on the role of money in the economy and the parameters of the optimal monetary policy.

The logic of the classical school is first described, then the features of Keynesian theory and the fundamental points of the new institutional economics are analyzed. The logical outcome of this analysis should be a consideration of the key features of contemporary neoclassical, neo-Keynesian, and postKeynesian views on money and banks.

According to R. Werner (Werner, 2012), the financial crisis of 2008-2009 created a kind of consensus among economists of various schools and areas on the need to include the peculiarities of the banking system functioning in existing macroeconomic models. Previously, the relevant issues were either not considered significant or received a fragmentary interpretation, which did not provide a considerable impact on the fundamentals of economic life in general or monetary policy in particular.

\section{The logic of the classical school representatives}

It is well known that the creators of classical theory (A. Smith, D. Ricardo) denied the dependence of economic growth on the amount of money in circulation, in connection with the denial of the previous postulates of mercantilism about the determining influence of the accumulated gold and silver reserves on the wealth of nations. As the value of accumulated precious metal inventories increased, the price level rose, and at the same time investment incentives as a factor in longterm growth weakened. So far, such considerations have materialized in the thesis that "money is neutral to income"; accordingly, there is no need to analyze the functioning of the banking system, which only serves the money supply, nothing more (Dostaler \& Maris, 2000). No later than the late 1980s, Nobel Laureate R. Lucas (Lucas, 1988) said that economists "greatly exaggerate" the impact of the functioning of the financial system on economic growth.

Nevertheless, classical school economists have recognized that the money supply proposition can be a source of macroeconomic imbalances in the short term (Smithin, 2002). Keynesian school economists recognize that money can be as important factor in production as capital or labor. The discussion between the proponents of both classical and Keynesian is further complicated by the contradictions between the proponents of the three alternative views of money, the Austrian, the Marxist, and the post-Keynesian.

Monetarism first emerged as one of the strands of Keynesian theory. The proponents of monetarism initially denied only the dependence of the demand for money on interest rates (vertical LM line), and considered the dependence of investment and private consumption on the cost of credit resources high (horizontal IS line). Under such conditions, fiscal policy is unable to stimulate incomes while maintaining the effectiveness of monetary policy. However, it was later proven that the "monetary" form of the IS and LM lines leads to the absence of the influence of the money supply on income, given the labor market dependencies (AD-AS model). But by the late 1950s it had become so transformed that its proponents began to accept the incomeneutral monetary policy (GDP) thesis. Ideologists of monetarism such as A. Marshall (1923) or M. Friedman (1948) recognized the need for institutional measures to reduce information asymmetry and develop the credit market. Banks were recognized not only as an important element in open market operations, which were supposed to regulate the money supply and the interest rate, but also as a factor in the investment process.

\section{The logic of the neoclassical school representatives}

Modern neoclassical models combine the theoretical apparatus of long-term models of economic growth with analytical constructions of monetary policy. For example, M. Goodfriend and B. McCallum (Goodfriend \& McCallum, 2007) proposed a neoclassical model that takes into account the 
influence of money supply and the banking system in a standard theoretical design with rational expectations. The example of the United States shows that changes in the performance of the banking system or the quality of collateral assets require significant changes in central bank rates. Some neoclassical models even recognize the role of consumer lending as a factor in monetary policy, which explains the features of "catching up" economic growth in a monetary union with industrialized countries (Backe \& Wojcik, 2008).

D. Levine (Levine, 2004) identifies the following mechanisms for a favorable relationship between the financial system and economic growth: 1) the accumulation of savings for the lending of investment projects and innovations that improve the allocation of resources; 2) providing information on investment opportunities (financial intermediaries reduce the cost of collecting and obtaining such information); 3) monitoring of the investment process and the impact on the management of corporations; 4) diversification and risk management; 5) exchange of goods and services. The financial sector stimulates economic growth through support for public sector investment projects and opportunities for intertemporal smoothing of private consumption and investment in human capital.

Close to the predictions of neoclassical models are the arguments of individual economists such as Hodgman (1961), King (1986) or Sinkey (1979), who emphasize the importance of banks as a means of obtaining a monetary multiplier effect from the expansion of the deposit base. This corresponds to the positioning of banks as intermediaries between savings owners and borrowers. Differences from the situation until the middle of the twentieth century are that modern banks are able to generate money supply without attracting deposits from households and businesses (the effect of a banking multiplier). This feature allows you to neutralize one of the factors reducing aggregate demand, because the accumulation of funds on deposits in one way or another limits aggregate demand. Negative side effects are an increase in the risks of banking in the economy with an accelerated growth of money supply. Usually, the "surplus" of money supply is accompanied by accelerating inflation, the emergence of various "bubbles" and distortion of investment "signals", which ultimately leads to a cyclical decline in production.

\section{The logic of the Keynesian school representatives}

Despite the above-mentioned possibilities for taking into account the peculiarities of the banking system in neoclassical models, objectively the effect of the banking multiplier is an argument in favor of Keynesian models with the stimulation of aggregate demand. However, this is not the case. Initially, Keynesian school supporters focused on the feasibility of fiscal instruments, as it was a combination of a significant dependence of money demand on interest rates with a weak dependence on this indicator of private consumption and investment; under such conditions, monetary policy became incapable of stimulating aggregate demand, and therefore interest in banking was not properly justified. Although D. M. Keynes recognized the importance of money as an element of contracts between entrepreneurs (Davidson, 2007), the feasibility of a two-tier banking system and the use of the central bank rate to regulate lending (Huber, 2014), in practice he was primarily concerned with the consequence of reducing of money supply which can lead to a wave of "bankruptcies, defaults and failures" (Dimand, 2011). The threat of inflation and related crises in the banking system has not been considered. Similarly, D. M. Keynes repeatedly stressed the risks of over-lending and the emergence of various price "bubbles", but later supporters of the Keynesian school mostly supported the development of bank lending. For example, in the early 1950s, D. Robinson claimed that banks did not respond sufficiently to postwar economic growth (Robinson, 1952).

The high inflation of the 1960s and 1970s led to a departure from Keynesian economic policy schemes in favor of neoclassical models with rational expectations, which denied the effectiveness of the expected changes in the money supply. From the early 1980s, the academic environment began to be dominated by models of the Real Business Cycle (RBC), which did not provide for the influence of price factors on the dynamics of the equilibrium trend of GDP. However, neo-Keynesian models soon emerged, which included price stability mechanisms (at least in the short term) in RBC models.

Gradually, a class of Dynamic Stochastic General Equilibrium - (DSGE) models emerged, which are now the main tools for analyzing monetary policy in central bank research units. Although such models are a holistic synthesis of methodological principles regarding the lack of flexibility of nominal wages and prices, the global financial crisis of 2008-2009 drew attention to their main drawback - the lack of detailed, and therefore realistic modeling of incentives, restrictions and intermediaries' financial behavior, including banks (Cukierman, 2011). It has been suggested that just as the Great Depression of 1929-1933 radically changed views on the economic policies of the then states, the Great Recession of 2008-2009 will stimulate a revision of the dominant views on monetary policy.

Under the influence of the crisis of 2008-2009, the positions of critics of the above-mentioned economic mainstream, which largely denies the significant 
impact of the money supply and banking system on economic growth, were strengthened. R. Werner notes that by the mid-1980s almost all models (classical, most of neoclassical ones, Keynesian, monetary and post-Keynesian, as well as most eclectic models) included a quantitative equation of money circulation: $M V=P Y$ where $M-$ money supply (monetary aggregates M0, M1, M2, M3 or M4); $V$ - money velocity (initially measured by the frequency of gold turnover during the observation period); $P$ - GDP deflator (price level); and $Y$ - income in real terms (GDP) (Werner, 2012). However, since the early 1980s, the adequacy of the quantitative equation of money circulation has been undermined by empirical studies that have shown volatility in the velocity of money and the demand for money. Negligence of the banking system occurred despite a significant number of banking crises - more than 100 in the postwar years. Similarly, there is no evidence of a significant effect of interest rates on cyclical dynamics, at least such an effect is much weaker than theoretical models suggest. There are also no signs of the determining influence of aggregate supply factors.

Somewhat paradoxically, the significant growth of the financial sector since the early 1980s is often seen as an argument against the neoclassical interpretation of monetary policy, which in fact never provided benefits from the issuance of money. For example, K. Bresser-Pereira considers the financial crisis of 2008-2009 as a consequence not only of "fictitious" financial wealth, but also of "reactionary" ideology of neoliberalism, based on assumptions about self-regulation of financial and commodity markets. This is contrasted with the period of "30 brilliant years of capitalism" (1948-1977), when government regulation avoided serious crises, while at the same time there was a steady increase in the welfare of the largest industrialized countries. Instead, the deregulation of the 1980s and 1990s, especially in the financial sphere, created the preconditions for chaotic and unstable development.

Criticism of the financial mechanisms of the last three decades has sufficient grounds in empirical research. In particular, an inverse relationship between private sector lending and economic growth was found for 16 CEE countries; instead, the money supply has a favorable effect (Petkovski \& Kjosevski, 2014). The obtained result is explained by the large volume of non-performing loans and numerous banking crises since the beginning of the transition period. To improve the situation, it is proposed to institutionally strengthen the banking system and expand the range of banking services.

It should be recognized that some supporters of neoclassical models also offer measures to reorient banks and financial companies to lending to the real sector, especially in economically backward regions (Uysal, 2019). This should increase the demand for money, in addition to the use of national currencies in bilateral trade. As early as the early 1930s, I. Fischer claimed that investment was necessary for GDP growth to exceed interest rates (this was necessary to prevent debt growth). However, this position has its own drawbacks. As shown by P. Samuelson (1958) and J. Tyrol (1985), given the high rate of GDP growth and low interest rates, various "bubbles" in the markets of individual assets can last quite a long time (The Economist, 2020).

In our opinion, it is incorrect to identify the processes of globalization and the excessive growth of financial markets with the logic of neoclassical models of economic development. Firstly, neoclassical models do not provide any long-term benefits from excessive money supply, and this is usually the root cause of crises. Secondly, openness to capital flows alone is not a problem unless confidence in the economy is lost and the various financial sector regulators are strong enough to prevent speculative processes. In general, this draws attention to the root causes of the increase in monetary aggregates. If this is due to increased savings and in a reliable macroeconomic environment, there is no reason for a crisis. Otherwise, in the case of accelerated growth of the money supply, which can occur due to many reasons: a) attempts to monetize the inflow of capital and thus avoid the strengthening of the currency; b) lobbying efforts of the banking sector interested in increasing consumer lending; c) populism in economic policy, which does not allow to control the budget deficit.

Recently, representatives of the neo-Keynesian and post-Keynesian trends have been actively promoting the benefits of money endogenization, when the supply and demand of the money supply respond to the level of income; relevant issues are often neglected by representatives of the neoclassical school (Georg \& Pasche, 2008). Neo-Keynesian models use the Taylor rule, when the interest rate is determined on the basis of the achieved level of inflation and the phase of the business cycle. Supporters of the post-Keynesian trend are divided into two strands, accommodationism and structuralism, which share assumptions about the emission of the banking system, but diverge in the treatment of bank reserves. Proponents of the first argue that an increase in demand for credit requires an additional increase in the central bank's monetary base (while banking activity does not change significantly). Instead, supporters of structuralism are convinced that in response to increasing demand for credit, it is necessary to change the structure of assets and liabilities of the banking system.

Proponents of the accommodative approach to monetary policy see the origins of their own position in the position of economists of the Austrian school 
since the early twentieth century (Dow, 2011). It is claimed that the endogeneity of the monetary base corresponds to the realities of the current behavior of most central banks, especially the Anglo-Saxon countries (USA, Canada). In particular, it concerns the ability of central banks to maintain a stable level of short-term interest rates and to influence the behavior of the banking system, which prevents the emergence of an "excessive" supply of money stock.

Proponents of the structuralist approach, on the other hand, convincingly claim that central banks in the United States, the United Kingdom, and the eurozone have shown their own inability to control the appropriate level of money supply (Dow, 2011). This requires the management of bank reserves, which will allow to form the appropriate preferences of commercial banks for lending. Banks influence lending volumes by inversely affecting the central bank's refinancing rate, setting interest rates on loans and deposits due to the oligopolistic structure of the financial market, trying to avoid reserves and increasing equity, and determining additional conditions for obtaining loans. Growing competition between banks and non-banking institutions has led to a process of financial deregulation, which has led to excessive risks - especially in the banking system.

Assessing the arguments of both neo-Keynesian and post-Keynesian trends, the current situation with a record low interest rate objectively weakens the argument in favor of using the Taylor rule as a regulator of money supply. On the other hand, supporters of the post-Keynesian trend negatively assess the consequences of the "surplus" of the money supply in the pre-crisis years of 2002-2008, but did not form realistic proposals for ways to limit the excessive growth of the money supply. Typically, raising interest rates is criticized as hindering investment, while measures to administer bank reserves may be ineffective. Instead, the use of bank reserves to manage the money supply may be accompanied by an increase in interest rates.

\section{The logic of the post-Keynesian school representatives.}

Over the last decade, representatives of the postKeynesian school have attempted to create a new holistic theory of monetary policy (Modern Monetary Theory, MMT) (Wray, 2019). The starting point is the endogeneity of the stock of money, which depends not on the savings of the population, but on the volume of public debt. The increase in the central bank's monetary base may be due to an increase in either government spending or public debt. In some ways, the second option is even more important, since government spending is financed by government loans. This position is fully consistent with the views of the Keynesian school, according to which fiscal policy is dominant. The central bank has no ability to control the stock of money, but can only determine the level of short-term interest rates, as in the standard neo-Keynesian models. However, this is not enough to maintain the balance of the money market.

The equilibrium level of the monetary base, which corresponds to the optimal supply of money, can only be determined by means of open market operations with government bonds. Thus, public debt is not so much necessary for government spending as it is for money management. It is this thesis that determines the popularity of MMT, as it is about removing restrictions on increasing the national debt and budget deficit (Coats, 2019). The only limitation for the emission financing of the budget deficit is the availability of productive resources in the economy (inflation will appear only after some optimal level of income at full employment). It is advisable to maintain the interest rate at "zero" level, which will stimulate investment and reduce the cost of servicing the public debt.

Such proposals are criticized from several perspectives: recognition of inflation only when the economy "overheats," exaggeration of the impact of fiscal policy and the ability of current government spending to generate tax revenues in the future, and lack of guarantees regarding the public debt (Sumner \& Horan, 2019).

T. Pelley (Palley, 2019) calls MMT a "simplified and incomplete" interpretation of long-known Keynesian ideas. One of the biggest drawbacks of the new theory is that it ignores the expectations of market participants. If monetary issuance raises expectations of faster inflation in the future, it is bound to raise long-term interest rates. Accordingly, the cost of long-term loans, which mainly finance investment projects, will rise. Instead, cheap short-term loans are likely to lead to "bubbles" in individual asset markets.

MMT theorists believe that deposits do not serve as a source of credit, but rather that the lending process creates the corresponding deposits (Huber, 2014). Accordingly, investments do not depend on deposits. The stock of money is not created by the central bank, but by the banking system. Loans are first made according to the demand for them, and only then do banks receive proper reserves from the central bank. Modern banking systems have been criticized for instability, asset inflation, the redistribution of monetary assets in favor of the financial sector, and increased vulnerability to crises. In this context, the current practice of partial provisioning and the existing paradigm where a certain target level of inflation is seen as an indicator of the adequacy of the money supply are criticized.

In assessing MMT's arguments, it should be noted that assumptions about the emission financing of 
budget deficits on a permanent basis can at most be temporary and are applicable mainly to industrialized countries with developed financial markets and high confidence in the economy. Low-income countries clearly lack confidence in their ability to service their own public debt by borrowing in local currency, accelerating inflation and ending the experiment of stimulating the economy by issuing fiscal deficit financing.

Like the evolution of views on banks in the Keynesian school, the arguments of institutional theorists in explaining economic processes have undergone equally radical changes. Initially such representatives of institutionalism as T. Veblen (1907) and D. Commons (1934) considered banking capital "parasitic" and denied the favorable impact of the banking system on economic growth (Zavadska, 2018). Socio-psychological factors in the behavior of market participants seemed much more important. In the post-war years the idea of the negative impact of banks on the economy was shared by D. Galbraith (1967). However, the institutional school theorists were the first to identify the importance of analyzing economic processes, taking into account legal and political factors. Later, the relevant arguments were developed by such representatives of the new institutional school as R. Coase (1990) and O. North (2005), who recognized the possibility and necessity of state regulation of monetary, financial and credit institutions. The study of such categories as "consumption", "utility" and "alternative means" "revived" the earlier proposals of J. Schumpeter (1912) on the recognition of the constructive role of banks in economic life and the need for their autonomy, but subject to strengthening the links with the real economy and the formation of a market for banking products and services.

\section{The logic of the new institutional school representatives}

Today, supporters of the new institutional school emphasize the importance of exploring the conditions that impede compliance with contracts (Currie \& Messori, 1998). This is important for the banking sector, because non-repayment of credit is the basis for crises. The main reason is considered to be an increase in transactional funds. The focus on contract compliance is close to neo-Keynesian models, which assume several equilibrium states depending on the state of individual markets, but in this case there are imbalances between labor supply and demand, savings and investment, and so on.

The global debate about the role of banks in the economy and the architecture of monetary policy resonates in Ukraine. Proponents of neo- and postKeynesian orientation clearly predominate. It should be noted that all proposals to stimulate economic growth in Ukraine call for an increase in the money supply and lending.

\section{Conclusions}

Based on the analysis, we can conclude that the banking system and the process of money emission influences not only short-term (cyclical), but can also affect long-term income. The post-crisis situation of 2010-2020, when interest rates fell to record lows and governments borrowed heavily to provide fiscal stimulus to the economy, is used by proponents of postKeynesianism, the so-called Modern Monetary Theory (MMT). Assumptions about the emission financing of budget deficits on a permanent basis can at most be temporary and apply mainly to industrialized countries with developed financial markets and a high level of confidence in the economy. It is a mistake to equate the processes of globalization and the excessive growth of financial markets with the logic of neoclassical models of economic development, since these models do not envisage any benefits from the excessive supply of money. Openness in itself to capital flows is not a problem unless confidence in the economy is lost, the money supply is increased by savings growth, there are no excessive budget deficits, and the various financial sector regulators are robust enough to prevent speculative processes. Taylor's rule is sufficient to recognize the endogenization of the money supply, although at record low interest rates the inadequacy of the relevant central bank policy should be recognized. At the same time, supporters of post-Keynesianism have no realistic proposals on how to limit the excessive growth of money (administrative measures may be ineffective, and the use of bank reserves to manage the money supply may be accompanied by an increase in interest rates).

\section{References:}

Backe, P., \& Wojcik, C. (2008). Credit booms, monetary integration and the new neoclassical synthesis. Journal of Banking \& Finance, 32, 458-470.

Coats, W. (2019). Modern Monetary Theory: A Critique. Cato Journal, 39(3), 563-576. DOI: https://doi.org/ 10.36009/CJ.39.3.4

Cukierman, A. (2011). The great depression, the global financial crisis and old versus new keynesian thinking: what have we learned and what remains to be learned? DOI: https://doi.org/10.1007/978-3-642-14409-7_12

Currie, M., \& Messori, M. (1998). New Institutional and New Keynesian Economics. In: Arena R., Longhi C. (eds.), Markets and Organization. Springer, Berlin, Heidelberg. DOI: https://doi.org/10.1007/978-3-642-72043-7_8 
Davidson, P. (2007). Keynes and Money. In: A Handbook of Alternative Monetary Economics / Edited by Philip Arestis and Malcolm Sawyer. Edward Elgar Publishing, 544 p.

Dimand, R. (2011). The Consequences to the Banks of the Collapse of Money. Available at: http://202.166.170.213:8080/xmlui/bitstream/handle/123456789/1425/Perspectives\%20on\%20Keynesian \%20Economics\%20by\%20Arie\%20Arnon.pdf? sequence=1\&isAllowed=y\#page $=249$

Dostaler, G., \& Maris, B. (2000). Dr Freud and Mr Keynes onmoney and capitalism. Routledge International Studies in Money and Banking.

Dow, S. C. (2011). Endogenous money: Structuralist. In: P. Arestis and M. Sawyer (eds), A Handbook of Alternative Monetary Economics. Cheltenham, UK: Edward Elgar.

Georg, C.-P., \& Pasche, M. (2008). Endogenous money: on banking behaviour in new and post Keynesian models. Jena Economic Research Papers, 65, 30. Available at: https://www.econstor.eu/handle/10419/31770

Goodfriend, M., \& McCallum, B. T. (2007). Banking and Interest Rates in Monetary Policy Analysis: A Quantitative Exploration. Journal of Monetary Economics, 54(5), 1480-1507.

Huber, J. (2014). Modern Money Theory and New Currency Theory. Real-world economics review, 66, 38-57.

Levine, R. (2004). Finance and Growth: Theory and Evidence National Bureau of Economic Research. Working Paper, 10766, 116. DOI: https://doi.org/10.3386/w10766

Lucas, R. (1988). On the mechanics of economic development. Journal of Monetary Economics, 22(1), 3-42.

Palley, T. I. (2019). What's wrong with Modern Money Theory (MMT): a critical primer. FMM Working paper, 44. Available at: https://www.econstor.eu/handle/10419/213401

Petkovski, M., \& Kjosevski, J. (2014). Does banking sector development promote economic growth? An empirical analysis for selected countries in Central and South Eastern Europe. Economic Research-Ekonomska Istraživanja, 27(1), 55-66. DOI: https://doi.org/10.1080/1331677X.2014.947107

Robinson, J. (1952). The Generalization of the General Theory. In: The Rate of Interest and Other Essays. J. Robinson (ed.). London: MacMillan, 164 p. DOI: https://doi.org/10.1007/978-1-349-16188-1

Smithin, J. (2002). What is money? Introduction. J. Smithin (ed.). London: N.Y. Routledge, pp. 1-15.

Sumner, S., \& Horan, P. (2019). How Reliable Is Modern Monetary Theory as a Guide to Policy? Mercatus Center at George Mason University.

The Economist (2020). Can China's economic miracle continue? Finance \& Economics. Available at: https://www.economist.com/finance-and-economics/2020/09/26/can-chinas-economic-miracle-continue

Uysal, G. (2019). New Version of IS-LM: Neoclassical Monetarism. Economics World, 7(3), $140-145$. DOI: https://doi.org/10.17265/2328-7144/2019.03.004

Werner, R. (2012). Towards a new research programme on 'banking and the economy' - Implications of the Quantity Theory of Credit for the prevention and resolution of banking and debt crises. International Review of Financial Analysis, 25, 1-17.

Werner, R. (2012). Towards a new research programme on 'banking and the economy' - Implications of the Quantity Theory of Credit for the prevention and resolution of banking and debt crises. International Review of Financial Analysis, 25, 1-17.

Wray, L. (2019). Alternative paths to modern money theory. Available at: http://www.paecon.net/PAEReview/ issue89/Wray89.pdf (accessed 01 October 2020).

Zavadska, D. (2018). Determining the role of banks in the financing of innovative development processes of the economy. Baltic Journal of Economic Studies, 4(3), 68-73. DOI: https://doi.org/10.30525/2256-0742/ 2018-4-3-68-73 